\title{
Fostering Innovation and Entrepreneurship in Brazil through Private Equity and Venture Capital Public Policies
}

\author{
Caio Ramalho ${ }^{1}$ \\ caio.ramalho@fgv.br
}

First Draft: October, 2009

This Draft: June, 2010

\begin{abstract}
It is well documented the positive impact of the Private Equity and Venture Capital (PE/VC) industry on the creation and development of highly successful innovative companies in a few countries, mainly in the United States. PE/VC firms provide not only capital to startups and small and medium enterprises (SMEs) that usually have financing gap, especially in emerging markets, but also strategic resources that enable these enterprises to commercialize innovation. As consequence, government incentive and nurture of local PE/VC industries would be expected in emerging economies due to innovation's importance to economic growth.
\end{abstract}

This paper aims to identify if the Brazilian government has supported local PE/VC industry throughout the years in order to foster favorable conditions to creating and developing successful innovative businesses. It also analyzes Brazil's main public policies towards $\mathrm{PE} / \mathrm{VC}$ and if they encompass all the three stages of its cycle - fundraising, investing and exiting.

I conducted an empirical research which collected primary data from a sample of $127 \mathrm{PE} / \mathrm{VC}$ firms (90\% of the population) operating in Brazil as of June, 2008. All firms answered a webbased questionnaire that collected quantitative data regarding their investment vehicles, portfolio companies, investments and exits. I compared the data obtained from the survey with the main local governmental PE/VC support programs.

First, I confirmed the hypothesis that the Brazilian government has been using the PE/VC industry as a public policy towards entrepreneurship and innovation. Second, I identified that although PE/VC public policies in Brazil are mostly concentrated in fundraising phase, they have been able to positively impact the whole cycle. Third, it became clear that the Brazilian government became more concerned about Seed and Venture Capital (VC) Early stages due to their importance to the entire PE/VC value chain. As consequence, I conclude that those public policies have been very important to build a dynamic and strong local PE/VC industry, whose committed capital grew 50\% per year between 2005 and 2008 to achieve US\$27 billion, which invested US\$ 11 billion, which employs 1,400 professionals (75\% with postgraduate degrees) and maintains 482 portfolio companies, mostly SMEs. In addition, PE/VC backed companies represented one third of the Initial Public Offerings (IPOs) that occurred in Brazil between 2004 and 2008 (approximately US\$15 billion).

\footnotetext{
${ }^{1}$ Researcher at GVcepe - Private Equity and Venture Capital Research Center at FGV-EAESP.
} 


\section{Introduction}

Throughout the years, innovation has been a key factor in world's economic growth due to the increase in companies' productivity (Schumpeter, 1934) and it has affected all the five forces that govern competition in any industry (Porter, 1979). In the United States, startups and SMEs creation has leveraged and empowered its economic development and competitiveness (Gompers 1994; Porter 1990).

The ability to combine resources (human, technology, capital, information, natural, etc) to innovate is a very important competence that is needed in order to gain competitive advantage. However, regardless their importance to the economy, startups and SMEs usually don't have access to proper resources needed to commercialize innovation, especially during their initial stage of lifecycle (Gompers, 1994; Pacheco and Spritzer, 2009). In emerging markets this framework is highlighted, and according to Andreassi and Siqueira (2006) lack of financing is one of startups' main mortality reasons in Brazil compared to developed countries. The ability to combine resources (financial, human, technology, information, natural, etc) to innovate is critical to blossom, develop competitive advantage, grow fast and survive.

$\mathrm{PE} / \mathrm{VC}$ presents a very interesting alternative to address this issue, especially to companies without historical financial statements (i.e. startups) or companies without tangibles assets that could be used as bank loans' guarantees (Sahlman, 1990). Not to mention that PE/VC firms provide not only capital but also assist the entrepreneurs on the decision making process in order to build successful businesses (Gorman and Sahlman, 1989). According to IHS Global Insight (2009), PE/VC-backed companies generated around US\$3 trillion in revenue ( $21 \%$ of the GDP) and employed over 12 million people in the United States in 2008. EVCA (2002) shows the PE/VC positive economic impact of PE/VC on companies' creation and growth.

The business environment for $\mathrm{PE} / \mathrm{VC}$ in Brazil has evolved in a consistent fashion over the last few years. According to EIU/LAVCA (2008) that qualifies the PE/VC environment in the region by identifying the positive and negative aspects for generating business within the industry in each country, Brazil jumped from 59 to 75 points in the ranking out of a possible 100 in only three years (2005 to 2008). The development and consolidation of the PE/VC environment in Brazil over the period in question is also pointed out by EMPEA/Coller Capital (2009) that rank the country as the second most attractive emerging market for $\mathrm{PE} / \mathrm{VC}$ investment over the next years.

\section{Literature Review}

The main challenge of any company is to achieve and sustain competitive advantage by developing dynamic capabilities that will modify or leverage its core competences based on the right resources. The ability to combine these appropriate resources (human, technology, capital, information, natural, etc) is a very important competence to innovate and to gain competitive advantage. (Porter 1979; Barney 1986; Prahalad and Hamel 1989; Hamel and Prahalad 1993; Teece and Pisano 1994; Mahoney 1995; Teece et al 1997; Bartlett and Ghoshal 2002). 
Christensen and Overdorf (2000) identify three factors that affect companies' innovation: resources, processes and values. Hardagon and Sutton (2000) state that innovative companies hire people with complementary skills and backgrounds, and that innovation is easily fostered if the right incentives and rewards are given to people. Through PE/VC it is possible to boost companies' growth compared to their peers (Hellman and Puri 2000; Engel 2002) which allow them to become more profitable (Sahlman 1990) throughout innovations.

According to Gompers (1994), Gompers and Lerner (2002) and Metrick (2007), PE/VC provides capital to finance innovation, especially high-risk but potentially high-reward projects. In fact, it has supported the creation and development of many of highly successful new revolutionary enterprises in the Human History, like Google, Microsoft, Netscape, Apple, eBay, Amazon, Sun Microsystems, Genentech, Yahoo, Intel, amongst others (Bygrave and Timmons, 1992; Gompers and Lerner, 2001b). Notwithstanding it is mainly associated with high-risk, potentially high-reward, leading edge technological projects, PE/VC industry has also backed a large number of innovative 'traditional' service companies, such as Staples, Starbucks, FedEx, Home Depot and TCBY - The Country's Best Yogurt (Gompers, 1994; Gompers and Lerner, 2001b; Gompers and Lerner, 2002; Metrick, 2007).

Further relating to the subject, PE/VC investments benefit startups and SMEs that normally have difficult to access ordinary financing, especially in emerging markets, due to their lack of tangible assets to use as collateral, heavy reliance on research \& development (R\&D) and human resources, operating losses for many years, and lower survivorship rates compared to more mature companies (Premus 1985; Gompers, 1994; Gompers and Lerner 2001a; Gompers and Lerner 2001b; Hall 2002; Smith and Smith 2002; Leeds 2003). Different from bank loans and short term debts, PE/VC will share upside and downside risks with the entrepreneur by taking an equity stake in the company and becoming a partner committed to its strong and sustainable growth (Engel, 2002; Gompers, 1994).

Notwithstanding the importance of the money provided by PE/VC firms the invested companies also benefit from a whole package of strategic non-financial resources that helps build successful enterprises and foster the blossom and development of highly innovative startups and SMEs: monitoring and performance tools, management professionalization, compensation arrangements, board of directors, budget structure, well established and high level networking, mentoring and advice to entrepreneurs, etc (Gorman and Sahlman 1989; Dotzler 2001; Gompers and Lerner, 2001b; Gompers and Lerner 2002; Keuschnigg, 2009). According to Bloom, Sadun and Van Reenen (2009), on average PE/VC-backed enterprises are better managed than non-PE/VC backed ones.

Sorensen (2007) suggests that PE/VC invests primarily in entrepreneurial innovative companies and it also has substantial impact on development of new technologies and Premus (1985) demonstrates that PE/VC and technological innovation growths are correlated. Kortum and Lerner (2001) show that PE/VC-backed companies are involved in important innovations based on patent amount in the U.S., while Bowonder and Mani (2002) show the impact of $\mathrm{PE} / \mathrm{VC}$ on financing innovation in India, and Tykova (2000) demonstrates a positive relation between patents creation and PE/VC investments in Germany.

According to Keuschnigg (2009) policy makers have been fostering favorable conditions through PE/VC to creating businesses. Gompers (1994) remembers the importance of the changes in the 1979 Employee Retirement Income Security Act (ERISA) and the consequent increase of pension funds' commitments to PE/VC in the U.S. Hirukawa and Ueda (2008) 
highlight the Yozma program in Israel and the Small Business Investment Company (SBIC) in the U.S., while Lerner (2002) agrees that government is highly interested on fostering innovation and support the PE/VC activity is a natural way to accomplish that goal.

Gompers (1994) concludes that promoting an efficient PE/VC industry should be the goal of any administration, although Brander, Du and Hellmann (2010) provide evidence that an extensive government support (or even a null support) doesn't maximize value creation and innovation benefits, and that moderate public activity in $\mathrm{PE} / \mathrm{VC}$ has the strongest performance.

\section{Methodology}

I conducted an empirical research which collected primary data from a sample of $127 \mathrm{PE} / \mathrm{VC}$ firms (90\% of the population) operating in Brazil as of June, 2008, independently of whether they have a local presence (office) and/or an investment vehicle already formed and operating. In other words, all PE/VC firms already defined and structured as such, even if they are still in the process of fundraising, were included in the PE/VC industry population. In addition, those $\mathrm{PE} / \mathrm{VC}$ organizations that informed that are no longer operating in the industry, those that are still not actively looking for business in Brazil and/or that don't consider themselves managers of $\mathrm{PE} / \mathrm{VC}$ investment vehicles were not considered in the population.

With these conditions and exclusions, each one of the $127 \mathrm{PE} / \mathrm{VC}$ firms filled out a web-based questionnaire which consisted of several questions related to five topics: a) General registration data for the $\mathrm{PE} / \mathrm{VC}$ organizations (ex. name, profile, category, origin); b) Investment vehicles (ex. name, legal structure, creation date, investor profiles, sector focus, stage focus, investments size); c) Portfolio companies; d) Investments and exits; and e) Fundraising prospects. All PE/VC firms answered a questionnaire that supplied quantitative data regarding investment vehicles, portfolio companies, investments and exits.

The information and statistics about PE/VC-related governmental programs were requested directly from the government agencies by e-mail and obtained from several public sources. IPOs information was collected from BM\&F Bovespa stock exchange using the Economatica software, in addition to from the Brazilian Security Exchange Commission (CVM) database. CVM's database was also used to double-check and validate some information provided by the PE/VC firms.

Supported on the extensive literature I assumed that PE/VC fosters innovation and highly impact entrepreneurship. As consequence, I considered whether public policies are effectively used to foster PE/VC in Brazil they have positive externalities on innovation in the country. As such, the work consists in an exploratory analysis of the Brazilian PE/VC public policies based on all the information gathered regarding the local PE/VC environment. Then I crosschecked and compared the compiled data obtained from the survey with the main local government PE/VC support programs based on the three stages of the PE/VC cycle fundraising; investing; and exiting - described by Gompers and Lerner (2002). 


\section{Main Findings}

The main objective is to identify whether the Brazilian government has been supporting local $\mathrm{PE} / \mathrm{VC}$ industry as a public policy towards innovation.

\subsection{Fundraising}

Over the last few years, driven by global liquidity and the strong growth of domestic economic indicators, the Brazilian PE/VC industry has gone through a very significant evolution. The growth of total committed capital has been impressive averaging $53.4 \%$ per year since 2004 to reach US\$26.65 billion (1.7\% of GDP) by June 2008.

Figure 1: Evolution of Committed Capital Allocated in Brazil (US\$ billion)

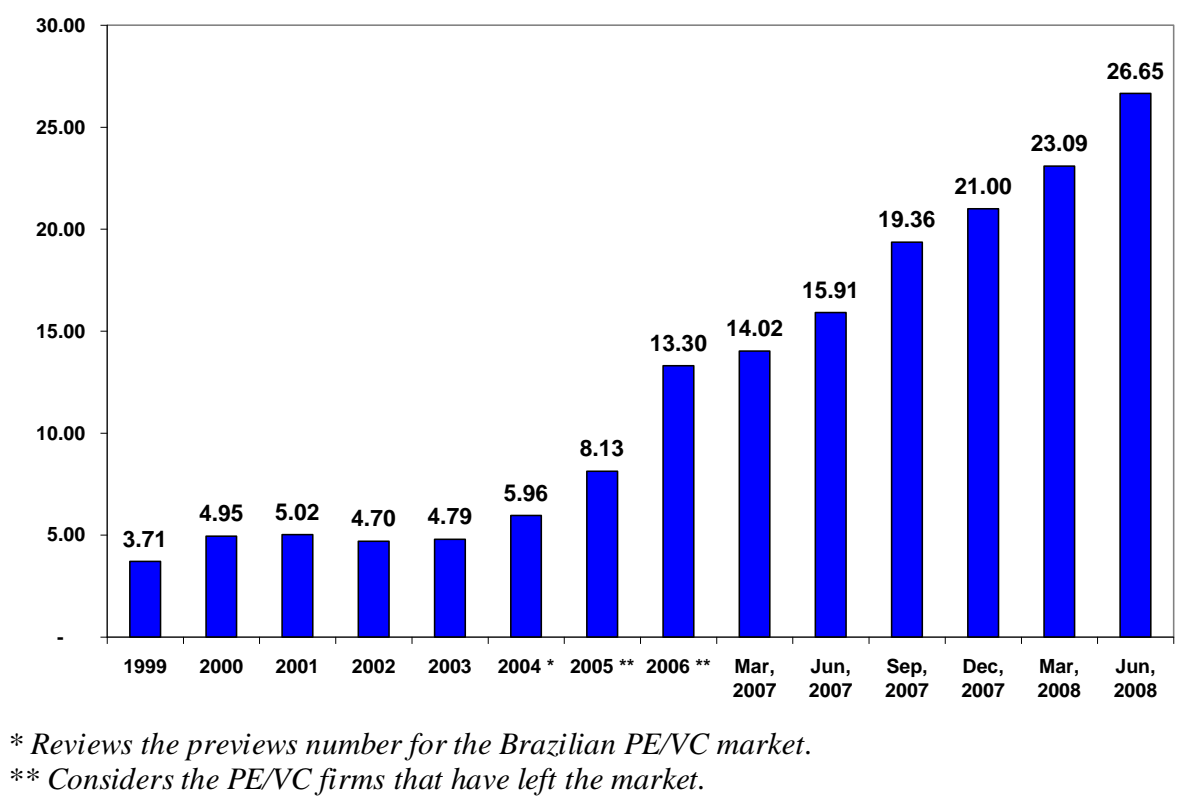

Approximately US\$9 billion was brought in by 52 of the $67 \mathrm{PE} / \mathrm{VC}$ firms that began operating from 2005 on and US $\$ 12$ billion by 26 of the $60 \mathrm{PE} / \mathrm{VC}$ firms that began operating in Brazil between 1981 and 2004. As of June 2008, 15 PE/VC firms were still in the process of raising its first time fund.

\subsubsection{The Brazilian Government as General Partner (GP)}

Notwithstanding the impressive increase of the Brazilian PE/VC industry, public sector's role structured as a PE/VC firm is not quantitative significant as the industry is characterized by independent general partners. The Brazilian Development Bank (BNDES) and the Brazilian Federal Loan and Saving Bank (CEF) are the only two state-owned PE/VC firm with a combined committed capital of US\$0.5 billion ( $2 \%$ of the total). 
Figure 2: Committed Capital by PE/VC Firms Category

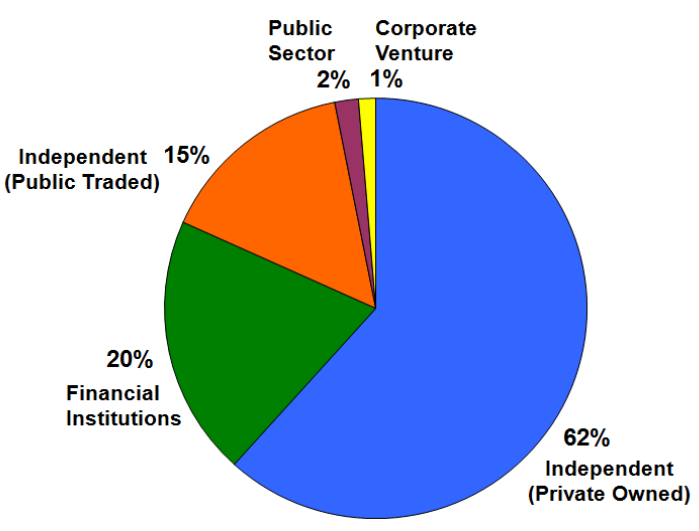

BNDES was created in 1952 and its investments in PE/VC are reminiscent of the 1980s when direct investments were prevalent, being one of the first Brazilian PE/VC firms. In the 1990s, BNDES took the first step toward outsourcing its PE/VC portfolios but it has never abandoned its role as PE/VC firm through direct investments.

CEF's role as GP is more recent than BNDES'. It started in 2008 as a public policy to invest in infrastructure using sources from the Unemployment Guarantee Fund (FGTS). Like BNDES, CEF not only is allowed to make direct investments as a typical PE/VC firm, but also can work as a limited partner and commit capital to third parties PE/VC firms.

\subsubsection{Government as Limited Partners (LPS)}

Brazilian public sector's participation as investor has been very important for the promotion and development of the Brazilian PE/VC industry. Since the 90's BNDES has invested in 33 investment vehicles ( 7 already fully divested) from 23 PE/VC firms, totaling US\$ 2.5 billion in capital commitments. Recently, BNDES launched a program to support seed capital called CRIATEC and chose a PE/VC firm to manage it. The CRIATED fund amounts US\$ 60 million of which $80 \%$ from BNDES and 20\% from Northeast Bank of Brazil (BNB), another state-owned institution, to invest in over 50 startups and small enterprises in the next 4-5 years.

The perception that innovative startups and SMEs couldn't find adequate mechanisms to finance their growth in the traditional credit system led the Brazilian Innovation Agency (FINEP), in partnership with the Inter-American Development Bank (IDB), created the INOVAR program in 2000 and INOVAR SEMENTE (to focus on seed capital) program in 2006. These two programs not only include FINEP and IDB but also another 13 investors, mostly local pension funds. From 2001 to June 2008, FINEP committed more than US\$130 million in 16 investment vehicles, of which 13 under INOVAR and 3 under INOVAR SEMENTE, from 10 PE/VC firms. FINEP commits up to $20 \%$ of the total resources approved for an investment vehicle under INOVAR program and $40 \%$ under INOVAR SEMENTE program.

The Brazilian Micro and Small Business Support Service (SEBRAE) is another government agency that invests in PE/VC. SEBRAE was created in 1972 to foster entrepreneurship and promote the development of SMEs in Brazil. It has also supported the INOVAR program since the beginning and from 1999 to 2004 it committed capital to $8 \mathrm{PE} / \mathrm{VC}$ investment vehicles. 
On total the Brazilian government has invested in more than 40 investment vehicles from 28 local PE/VC firms. It corresponds to $20 \%$ of total investment vehicles and PE/VC firms in the Brazilian market as of June 2008.

In addition to government agencies and state-owned banks capital commitments to PE/VC, the public policy is also present on pension funds' $\mathrm{PE} / \mathrm{VC}$ investments. The largest Brazilian pension funds are those from state-owned companies and as consequence they suffer political influence and key-managers appointments directly by the government or indirectly throughout their sponsor state-owned companies.

Table 1: Brazilian Pension Funds Total Assets Ranking

\begin{tabular}{|l|c|c|l|c|}
\hline \multicolumn{1}{|c|}{ Pension Fund Name } & $\begin{array}{c}\text { US\$ } \\
\text { Billion }\end{array}$ & $\%$ & \multicolumn{1}{|c|}{ Sponsor Company } & Type \\
\hline PREVI & 82.3 & $30 \%$ & Banco do Brasil & State-Owned \\
\hline PETROS & 24.8 & $9 \%$ & Petrobras & State-Owned \\
\hline FUNCEF & 20.1 & $7 \%$ & CEF & State-Owned \\
\hline Fundação CESP & 9.4 & $3 \%$ & CESP & State-Owned \\
\hline VALIA & 6,3 & $2 \%$ & Vale do Rio Doce & Private $\left(^{*}\right)$ \\
\hline ITAUBANCO & 5.8 & $2 \%$ & Itaú Bank & Private \\
\hline SISTEL & 5.7 & $2 \%$ & Several telecom companies (former Telebrás) & Private $(*)$ \\
\hline CENTRUS & 5.5 & $2 \%$ & The Brazilian Central Bank & State-Owned \\
\hline BANESPREV & 5.4 & $2 \%$ & Banespa & Private $(*)$ \\
\hline FORLUZ & 4.3 & $2 \%$ & CEMIG & State-Owned \\
\hline REAL GRANDEZA & 3.7 & $1 \%$ & FURNAS & State-Owned \\
\hline FAPES & 3.2 & $1 \%$ & BNDES & State-Owned \\
\hline Fundação COPEL & 2.8 & $1 \%$ & COPEL & State-Owned \\
\hline Cx. Emp. Usiminas & 2.5 & $1 \%$ & USIMINAS & Private $\left(^{*}\right)$ \\
\hline POSTALIS & 2.5 & $1 \%$ & The Brazilian Post and Telegraph Corporation & State-Owned \\
\hline Another 354 Pension Funds & 87.5 & $32 \%$ & - & - \\
\hline TOTAL & $\mathbf{2 7 1 . 7}$ & $\mathbf{1 0 0 \%}$ & - & - \\
\hline
\end{tabular}

* Privatized companies

Source: ABRAPP (2008) / Author's analysis

Capital commitments in PE/VC by pension funds amount USD 7.2 billion in Brazil (27\% of total). I estimate that 20 to 30 pension funds have capital commitments in PE/VC that total US\$ 6.4 billion, the equivalent of $3.0 \%$ of total pension fund's assets and $0.4 \%$ of the GDP.

Figure 3: Breakdown of Committed Capital by Investor Type

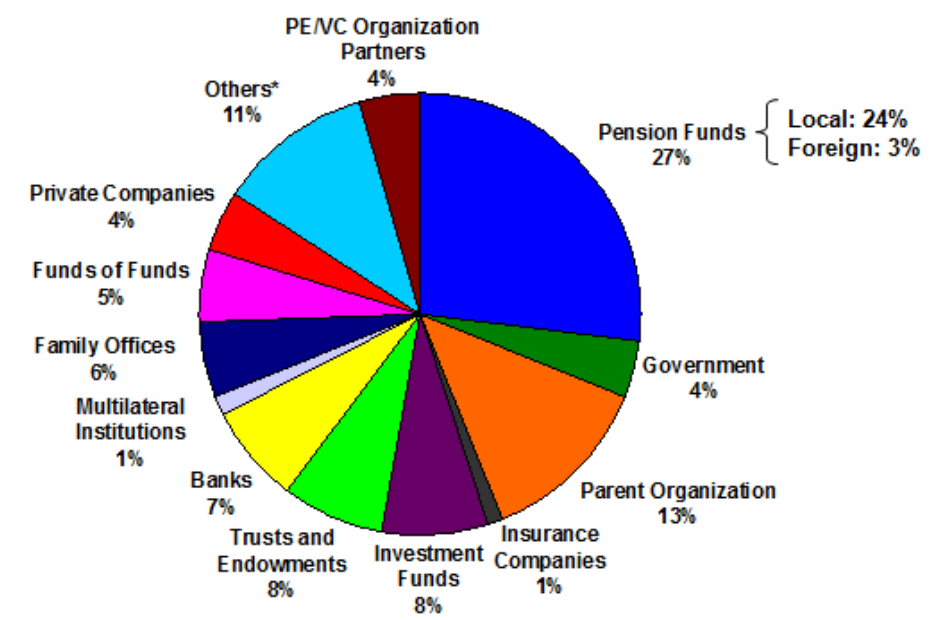

* Includes individuals and other types of investors not listed under the other options. 


\subsubsection{Regulation}

The CVM rule number 209 which created Fundos Mútuos de Investimentos em Empresas Emergentes (FMIEEs) in 1994 and CVM rule 391 which created Fundos de Investimentos em Participações (FIPs) in 2003 were conceived to deal with the absence of the concept of limited partnership in the Brazilian legislation.

Likewise ERISA in the U.S, the CVM rule 391 clarified and regulated the Brazilian pension funds PE/VC investments. Due to this regulation, the relative participation of pension funds in new funds reached $50 \%$, close to the level of $58 \%$ reached during the privatization era.

Figure 4: Pension Funds Stake in Committed Capital per Investment Vehicle Vintage

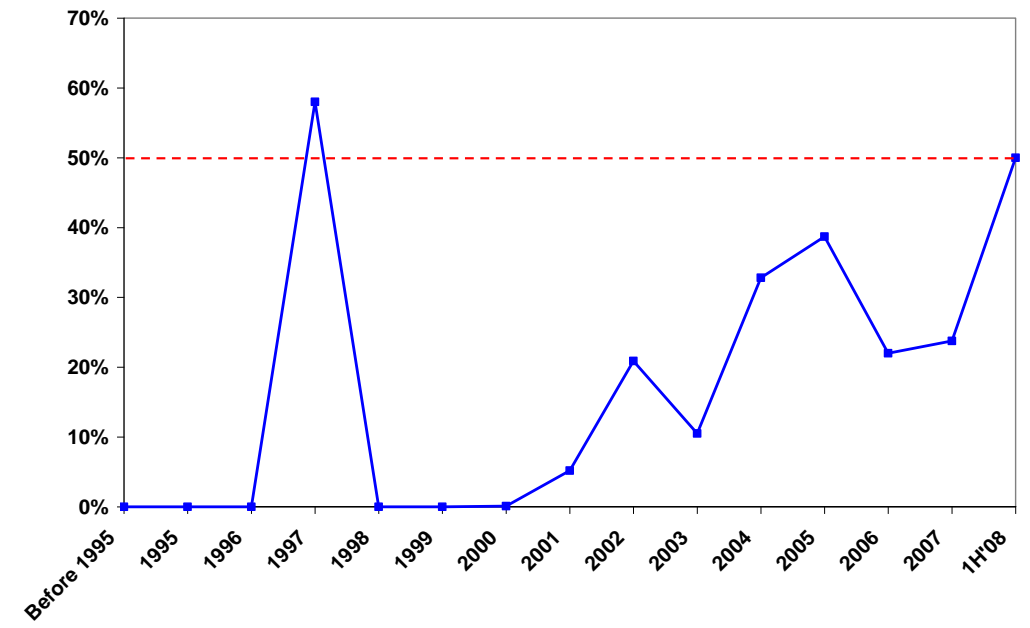

OBS: Sample size of 112 vehicles with committed capital of US\$18.1 billion.

The investment vehicles created under the CVM regulation went from 23\% in 2004 to $39 \%$ of capital commitments by June 30, 2008 and represented $40 \%$ of all PE/VC investment vehicles. This legal structure currently predominates in the industry, which shows the success of the institutional model created by the CVM in 2003 (CVM 391 - FIPs).

Figure 5: Breakdown of Committed Capital by Investor Type

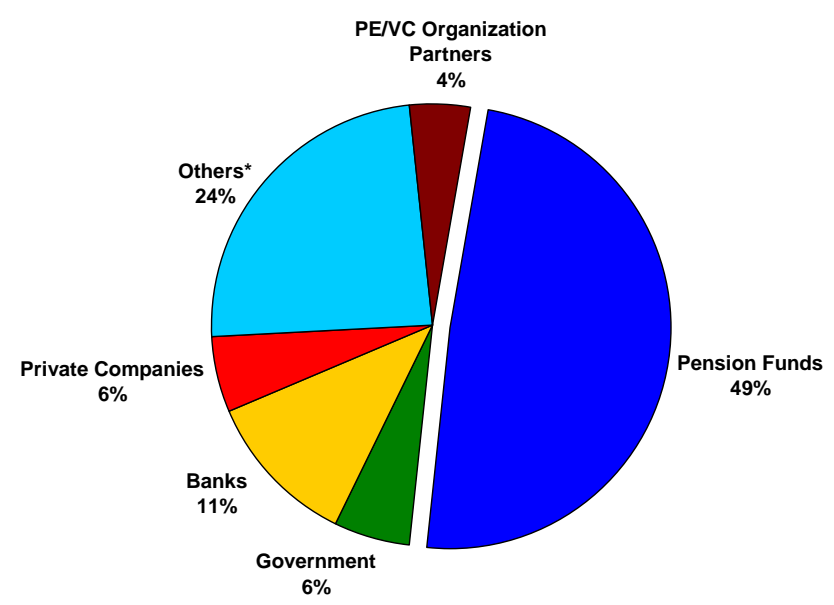

\subsection{Investing}

The great diversity of economic sectors constitutes an important aspect of the business model of the PE/VC industry. The 481 portfolio companies cover 26 industries and more than 40 sub-industries. 
Table 2: Portfolio Companies (June 2008)

\begin{tabular}{|c|c|c|c|c|c|c|c|c|}
\hline \multirow{2}{*}{ Industries } & \multicolumn{2}{|c|}{$\begin{array}{l}\text { BNDES as } \\
\text { PE/VC firm }\end{array}$} & \multicolumn{2}{|c|}{$\begin{array}{c}\text { Sponsored by } \\
\text { BNDES (1) }\end{array}$} & \multicolumn{2}{|c|}{$\begin{array}{l}\text { Sponsored by } \\
\text { FINEP (1) (2) }\end{array}$} & \multicolumn{2}{|c|}{$\begin{array}{c}\text { Total Industry } \\
\text { Portfolio }\end{array}$} \\
\hline & Units & $\%$ & Units & $\%$ & Units & $\%$ & Units & $\%$ \\
\hline IT & 13 & $33 \%$ & 21 & $33 \%$ & 13 & $42 \%$ & 109 & $23 \%$ \\
\hline Industrial Goods & 9 & $23 \%$ & 6 & $9 \%$ & 5 & $16 \%$ & 61 & $13 \%$ \\
\hline Real Estate & - & - & 1 & $2 \%$ & - & - & 60 & $12 \%$ \\
\hline Communication & - & - & 2 & $3 \%$ & 1 & $3 \%$ & 32 & $7 \%$ \\
\hline Energy & - & - & 10 & $16 \%$ & - & - & 29 & $6 \%$ \\
\hline Agribusiness & 1 & $3 \%$ & 4 & $6 \%$ & 1 & $3 \%$ & 21 & $4 \%$ \\
\hline Financial Services & - & - & - & - & - & - & 20 & $4 \%$ \\
\hline Biotech & 6 & $15 \%$ & 4 & $6 \%$ & 4 & $13 \%$ & 20 & $4 \%$ \\
\hline Retail & - & - & 1 & $2 \%$ & - & - & 19 & $4 \%$ \\
\hline Food and Beverage & 5 & $13 \%$ & 1 & $2 \%$ & - & - & 17 & $4 \%$ \\
\hline Medicine & 2 & $5 \%$ & 3 & $5 \%$ & 3 & $10 \%$ & 15 & $3 \%$ \\
\hline Telecom & 4 & $10 \%$ & 2 & $3 \%$ & 3 & $10 \%$ & 13 & $3 \%$ \\
\hline Transportation & - & - & 5 & $8 \%$ & - & - & 13 & $3 \%$ \\
\hline Logistics & - & - & 1 & $2 \%$ & - & - & 12 & $2 \%$ \\
\hline Education & - & - & - & - & - & - & 9 & $2 \%$ \\
\hline Others & - & - & 3 & $5 \%$ & 1 & $3 \%$ & 31 & $6 \%$ \\
\hline TOTAL & 40 & $100 \%$ & 64 & $100 \%$ & 31 & $100 \%$ & 481 & $100 \%$ \\
\hline
\end{tabular}

(1) Includes 12 companies (5 IT, 3 Industrial Goods, 1 Agribusiness, 1 Medicine, 1 Telecom, 1 Others ) invested by 6 vehicles co-invested with FINEP.

(2) INOVAR and INOVAR SEMENTE programs.

BNDES and FINEP together account, directly and indirectly, for $26 \%$ of total industry's portfolio companies. It is very impressive, especially considering that in Brazil the LPs have active influence in the investment committees. In addition, BNDES and FINEP have a stronger presence in highly innovative (IT, Biotech, Medicine) and strategic/infrastructure (Food, Energy, Telecom, Transportation) industries than the rest of the Brazilian PE/VC sector.

A total of $51 \%$ of the industry's portfolio companies are more mature companies, $43 \%$ are Private Equity - Expansion and 8\% are Private - Later Stage, but there also is a considerable volume of business in Venture Capital (34\%) with the greatest emphasis on the Early Stage $(17 \%)$. This denotes an important concentration on the intermediate stage of entrepreneurial development.

Figure 6: Portfolio Company Stages (as of June 30, 2008)

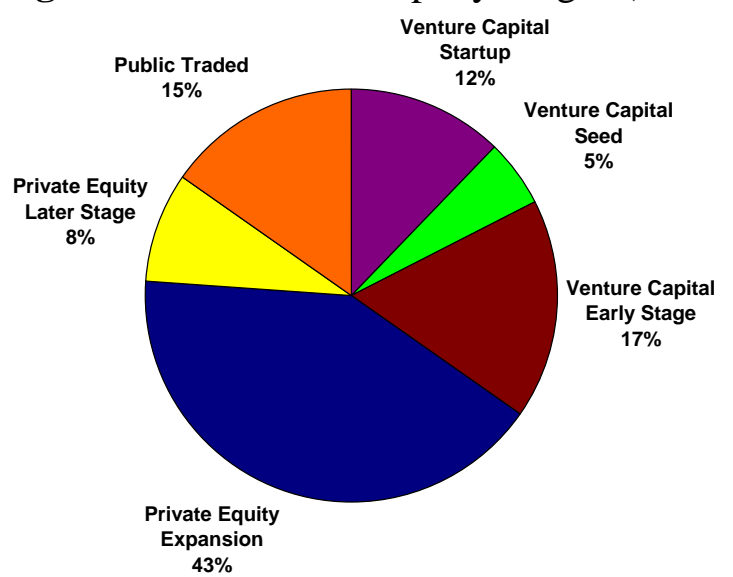

OBS: Considers the sample of 462 companies that reported their current stage of development (out of a total of 481 companies). 
There is a considerable volume of business in Venture Capital (34\%) with the greatest emphasis on the Early Stage (17\%), in addition to $43 \%$ of Private Equity Expansion, mostly medium size companies. This denotes an important concentration on the initial and intermediate stages of entrepreneurial development guaranteeing the consolidation of the links that permit sustained industry growth over the long term.

\subsubsection{Generating Deal Flow}

As a further support to the development of the PE/VC industry, FINEP organized several Forums under the INOVAR and INOVAR SEMENTE programs, with the objective of building the innovative entrepreneurial spirit of startups and SMEs, preparing them for receiving $\mathrm{PE} / \mathrm{VC}$ investment.

Since their creation, the FINEP Forums have supported a total of 243 innovative highly entrepreneurial companies: 162 in Venture Forum (focused on SMEs), 21 in the IPO Forum (aimed at innovative companies with the potential to be listed on the stock market), and 60 in the Seed Forum (focused on startups and seed capital). It is clear that FINEP's efforts with INOVAR and INOVAR SEMENTE together with the FINEP Forums have helped develop an entrepreneurial culture in the Brazilian $\mathrm{PE} / \mathrm{VC}$ industry over the past few years and nurture a deal flow to the PE/VC industry.

\subsection{Exiting}

There were 111 exits (total and partial) totaling US\$2 billion over the period from 2005 and June 2008 , of which $31 \%$ from venture capital and $50 \%$ from private equity stages.Trade sales represented around $1 / 3$ of the total number of exits in the industry over this period, while sales in the stock market represented $50 \%$ of the total quantity (whether they were through IPOs and divestitures due to them or sales of PIPEs.

Figure 7: Number of Exits by Type (January 2005 to June 2008)

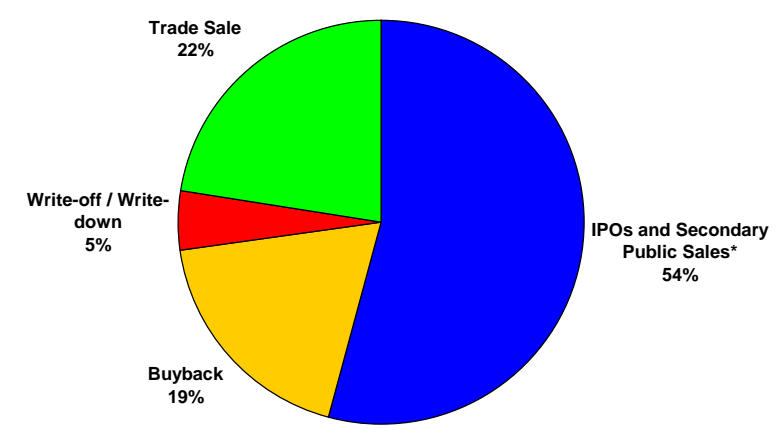

* Includes IPOs and secondary sales between funds.

OBS: Considers total and partial exits.

IPOs are considered exits' pot of gold for PE/VC investments worldwide; however it didn't constitute a viable alternative in Brazil during the 1980s and 1990s because of the volatile macroeconomic environment and high interest rates that prevailed in the country during this period. This is why few companies looked to the stock market for long term financing in Brazil, and consequently, the IPO market passed through a 'nuclear winter" period.

Nevertheless, with the improvement in the macroeconomic scenario and the increase in global liquidity, along with the reduction of interest rates, the stock market stood out again as an alternative long term investment. In fact, in the beginning of 2004 the Brazilian stock market took on a new momentum with the wave of IPOs set off by the exits from PE/VC 
organizations. From 2004 to June 2008, 110 IPOs were taken to market raising US\$ 53.3 billion, of which 39 companies had received PE/VC investments prior to their public offering.

Figure 8: Number of IPOs

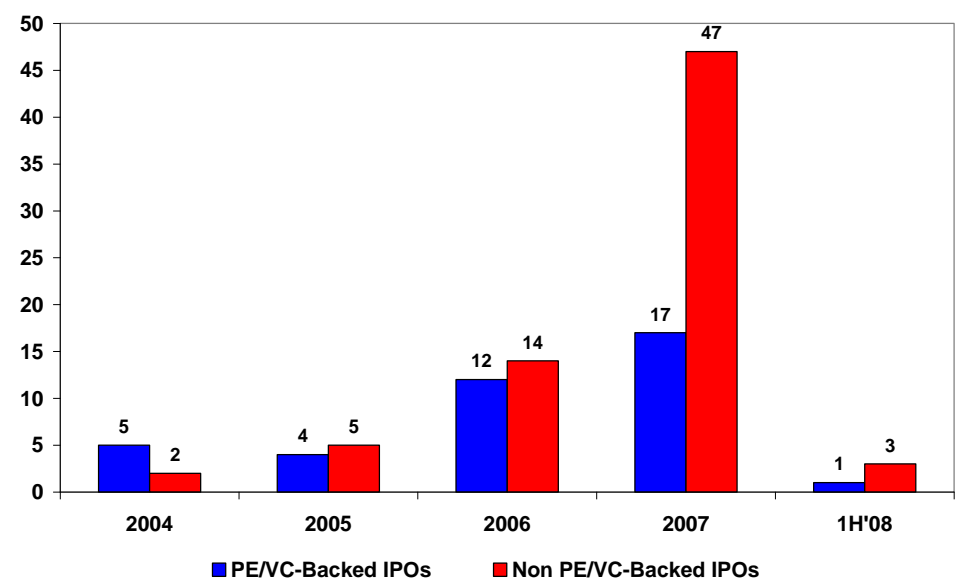

Source: Bovespa / Author's analysis

The total amount of money raised by companies that received PE/VC investments reached US\$ 16.4 billion from primary and secondary offerings, equivalent to $31 \%$ of the total volume of IPOs made during this period. Between May 2004 and June 2008, companies that received $\mathrm{PE} / \mathrm{VC}$ investments had an average return of $17.3 \%$ as opposed to $1.5 \%$ for the companies that did not receive $\mathrm{PE} / \mathrm{VC}$ investments, with $67 \%$ of the returns being positive for those that had received $\mathrm{PE} / \mathrm{VC}$ investments and $40 \%$ being positive for those that had not.

\section{Conclusions}

The PE/VC industry has been responsible for the creation and development of extremely successful technological businesses like Google, Microsoft, Netscape, eBay, Amazon, Yahoo, Intel and Genetech worldwide. Not to mention that it has also supported non-tech, but also highly innovative, 'traditional' companies such as Staples, Starbucks, FedEx and HomeDepot. $\mathrm{PE} / \mathrm{VC}$ provides not only capital to the enterprises but also strategic resources that allow the invested companies to differentiate and pursue a competitive advantage against its peers showing an impressive level of not only technological but also process, management and product innovations.

Due to its entrepreneurial vocation, several governments worldwide have elected the PE/VC as a key public policy toward innovation and entrepreneurship. Many have failed, but some succeeded as noted by Lerner (2009). Using public policies to foster PE/VC can be a disastrous waste of time and money, not to mention the real possibility to ruin any potential entrepreneurial and innovative initiatives. In emerging markets, this dilemma becomes even more dramatic since PE/VC can offer the only sustainable alternative to the financing gap faced by startups and SMEs. This is also the challenge for Brazil.

I confirmed the hypothesis that the Brazilian government has been using the PE/VC industry as a public policy towards innovation and high impact entrepreneurship. It is an established and partially coordinated national effort that accelerated in the 2000's leveraged by the economic stabilization and growth of Brazil. Two governmental institutions (BNDES and 
FINEP) are the main promoters of this policy with important implications to the whole PE/VC value chain.

I identified that the Brazilian PE/VC public policies are mostly concentrated in fundraising phase; however it has an enormous impact over the investing and exiting phases. Through BNDES, FINEP and SEBRAE, the Brazilian government has supported an impressive percentage of $\mathrm{PE} / \mathrm{VC}$ firms, all local players. In addition, the government is also present in $\mathrm{PE} / \mathrm{VC}$ through the state-owned pension funds that become one of industry's leading investors. Notwithstanding its role as LP and GP, the government also impacted the fundraising phase as it regulates the local PE/VC industry through CVM. All the local investment vehicles under CVM rule 209 or 391 must be registered at CVM likewise a stock market investment fund. Nevertheless, it became clear that the Brazilian government through BNDES and FINEP became more supportive to seed capital fundraising due to its importance to the whole PE/VC value chain. The next natural move should be a new CVM rule to specifically benefit the seed capital.

The investing phase is highly influenced by the fundraising public policies. BNDES and FINEP together account for a significant portion of the PE/VC industry portfolio. It is even more significant since the LPs have board seats on the investment committee in Brazil. Another interesting finding is that BNDES and FINEP portfolios have a stronger participation in highly innovative and strategic/infrastructure industries compared to the rest of the Brazilian PE/VC sector.

It is notorious the remarkable positive effect of the Brazilian public policies toward PE/VC since some PE/VC-backed innovative enterprises have arise in the country in the past few years like Submarino, DHC Outsourcing, Akwan, Allelyx, Buscapé, Lupatech, Bematech, Mandic BBS, GOL and DASA, just to mention a few, and were successfully sold by PE/VC firms. As consequence, from 2004 and June of 2008 around one third of IPOs in Brazil were PE/VC-backed companies (US\$ 16.4 billion) which presents evidence that public policy oriented to the $\mathrm{PE} / \mathrm{VC}$ cycle first stage has also produced a positive effect on the last (exiting) phase.

Notwithstanding the positive impact of the PE/VC public policies presented until now in Brazil, it is very important that the government considers the present framework as a temporary solution to an emerging PE/VC industry. The goal of the Brazilian PE/VC government should be strengthen the private institutions through the whole cycle in order to achieve the economic equilibrium and assure the long term sustainability of the local PE/VC market. 


\section{References}

ABRAPP. (2008) “Consolidado Estatístico - Junho 2008”. ABRAPP - Brazilian Association of Pension Funds report.

Andreassi, T. and Siqueira, E. (2006) "The Funding of New Technology-based Firms in Brazil". International Journal of Entrepreneurship and Innovation Management 6(4/5), 369382.

Barney, J. (1986) "Strategic Factor Markets: Expectations, Luck and Business Strategy". Management Science.

Bartlett, C. and Ghoshal, S. (2002) "Building competitive advantage through people”. MIT Sloan Management Review.

Bloom, N., Sadun, R. and Van Reenen, J. (2009). "Do Private Equity Owned Firms Have Better Management Practices?”. Centre for Economic Performance. Occasional Paper, n.24.

Bowonder, B and Mani, S. (2002) "Venture Capital and Innovation: The Indian Experience". In: Financial Systems, Corporate Investment in Innovation and Venture Capital". UNU/INTECH research project.

Brander, J., Du, Q. and Hellmann, T. (2010) “Governments as Venture Capitalists: Striking the Right Balance". In Globalization of Alternative Investments, Working Papers v.3: The Global Economic Impact of Private Equity Report 2010, World Economic Forum, pp 25-52

Bygrave, W. and Timmons, J. (1992) "Venture Capital at the Crossroads". Harvard Business School Press.

Christensen, C. and Overdorf, M. (2000) "Meeting the Challenge of Disruptive Change". Harvard Business Review, Mar-Apr, 2000.

Dotzler, F. (2001) “What Do Venture Capitalists Really Do, and Where Do They Learn to Do It? ". Journal of Private Equity. Winter, 2001.

EIU/LAVCA. (2008) "The Scorecard in the Private Equity and Venture Capital Environment in Latin America and the Caribbean". EIU - Economist Intelligence Unit and LAVCA - Latin American Venture Capital Association report.

EMPEA/Coller Capital. (2009) “Emerging Markets Private Equity Survey - 2009”. EMPEA - Emerging Markets Private Equity Association special report.

Engel, D. (2002). "The Impact of Venture Capital on Firm Growth: An Empirical Investigation”. Centre for European Economic Research, Discussion Paper 02-02.

EVCA. (2002) "Survey of the Economic and Social Impact of Venture Capital in Europe". EVCA - European Venture Capital Association research paper.

Gorman, M. and Sahlman, W. (1989) “What Do Venture Capitalists Do?” Journal of Business Venturing. 
Gompers, P. (1994) "The Rise and Fall of Venture Capital”. Business and Economic History 23(2), 1-18.

Gompers, P. and Lerner, J. (2001a) “The Money of Invention”. Harvard Business School Press.

Perspectives 15(2), 145-168

(2001b) “The Venture Capital Revolution”, Journal of Economic (2002) “The Venture Capital Cycle", MIT Press, Cambridge.

Hall, B. (2002) "The Financing of Research and Development”. NBER Working Paper 8773.

Hamel, G. and Prahalad, C. (1993) "Strategy as Stretch and Leverage”. Harvard Business Review, Vol.71(2), pp.75-84.

Hardagon, A. and Sutton, R. (2000). “Building an Innovation Factory”. Harvard Business Review, May-June.

Hellmann, T. and Puri, M. (2000) "The Interaction between Product Market and Financing Strategy: The Role of Venture Capital”. Review of Financial Studies 13, 959-984.

Hirukawa, M. and Ueda, M. (2008) "Venture Capital and Innovation: Which is First?". http://ssrn.com/abstract $=1242698$

IHS Global Insight. (2009) "Venture Impact - The Economic Importance of Venture CapitalBacked Companies to the U.S. Economy”. NVCA - National Venture Capital Association report. $5^{\text {th }}$ Edition.

Keuschnigg, C. (2009). "Public Policy, Venture Capital and Entrepreneurial Finance" forthcoming in: Cumming, D. (ed.), "Companion to Venture Capital”. New York: Wiley.

Kortum, S. and J. Lerner. (2001) "Does Venture Capital Spur Innovation?” in G. Libecap, ed., Entrepreneurial Inputs and Outcomes, Vol. 13, Amsterdam, Elsevier.

Leeds, R. (2003) “Financing Small Enterprises in Developing Nations". Transnational Publishers, New York.

Lerner, J. (2002) "Boom and Bust in the Venture Capital Industry and the Impact on Innovation”. Harvard NOM Working Paper No. 03-13.

Lerner, J. (2009) “Boulevard of Broken Dreams”. New Jersey: Princeton University Press.

Mahoney, J. (1995) "The Management of Resources and the Resources of Management". Journal of Business Research. Vol. 33, pp.91-101

Metrick, A. (2007) "Venture Capital and the Finance of Innovation". John Wiley and Sons, Inc. 
Pacheco, E. and Spritzer, I. (2009). "Mapeamento do fomento a Inovação Tecnológica no Brasil”. Revista INGEPRO, Vol.1, n.4.

Porter, M. (1979) “How Competitive Forces Shape Strategy". Harvard Business Review. Vol.57(2), Mar-Apr, pp. 137-145 . (1990) “The Competitive Advantage of Nations". New York: Free Press.

Prahalad, C. and Hamel, G. (1989) "The Core Competence of the Corporation". Harvard Business Review. Vol. 68(3), pp 63-76.

Premus, R. (1985) “Venture Capital and Innovation”. USGPO, Washington. D.C.

Sahlman, W. (1990) "The Structure and Governance of Venture Capital Organizations. Journal of Financial Economics”. Vol. 27(2), pp. 473-521.

Schumpeter, J. (1934). "The Theory of Economic Development". Oxford University Press.

Smith, R. and Smith, J. (2002) “Entrepreneurial Finance”. Wiley, New York

Sorensen, M. (2007). "Learning by Investing: Evidence from Venture Capital". Swedish Institute for Financial Research, n.53.

Teece, D. and Pisano, G. (1994) "The Dynamic Capabilities of Firms: An Introduction, Industrial and Corporate Change". Vol. 3(3), pp.537-556.

Teece, D., Pisano, G. and Shuen, A. (1997) "Dynamic Capabilities and Strategic Management”. Strategic Management Journal, Vol.18(7), pp. 509-533.

Tykvova, T. (2000) "Venture Capital in Germany and its Impact on Innovation". http://papers.ssrn.com/paper.taf?abstract_id=235512 